\title{
Slovenian Teachers' Elements of Support for Pupils with Learning Difficulties in Foreign Language Teaching at the Primary and Lower-Secondary Levels
}

\author{
Mihaela Brumen ${ }^{1}$, Lea Bračko ${ }^{2}$ \& Majda Schmidt Krajnc ${ }^{1}$ \\ ${ }^{1}$ Faculty of Education, University of Maribor, Maribor, Slovenia \\ ${ }^{2}$ Primary School Maribor, Maribor, Slovenia \\ Correspondence: Mihaela Brumen, Faculty of Education, University of Maribor, Koroska cesta 160, 2000 \\ Maribor, Slovenia. Tel: 386-2-2293-600. E-mail: mihaela.brumen@uni-mb.si
}

\author{
Received: February 14, 2014 Accepted: March 16, 2014 Online Published: April 14, 2014 \\ doi:10.5539/elt.v7n5p78 URL: http://dx.doi.org/10.5539/elt.v7n5p78
}

\begin{abstract}
The article concerns educational work with students who have learning difficulties with foreign languages in Slovenian primary schools. The aim of the research was to investigate current methodical and organisational elements of teacher's support in foreign language teaching for students (aged 9-15) with learning difficulties, according to the location of the school, being either urban or rural. A non-random sample was taken, which consisted of foreign language teachers who teach in the Slovenian primary and lower-secondary levels $(\mathrm{N}=47)$. An analysis of the results showed that there were no statistically significant differences between rural and urban schools concerning teacher-support for students with learning difficulties in learning English as a foreign language. The research shows that some of the sources of support for children with learning difficulties are relatively underutilized, even though they have proven to be effective when put into inclusive practice internationally.
\end{abstract}

Keywords: learning difficulties, foreign language, pupils, elements of teachers' support, primary, lower-secondary level

\section{Introduction}

In recent years, schools have been faced with a diverse student population. Classes now include students from different cultural and linguistic backgrounds; different religious, racial, and sexual orientations, as well as students with special needs (Sleeter \& Grant, 2003). It is becoming increasingly clear that schools should provide appropriate, high-quality and effective inclusive teaching for the various types of students (Booth \& Ainscow, 1998; Mitchell, 2008). This also applies to students with learning difficulties who are learning a foreign language. Knowledge of foreign languages is a necessity. Its value and advantages are mainly due to the modern mobility of cultures, the internationalization of businesses, global education and an ever-increasing multicultural society.

\section{Foreign Language Education in Slovenia}

Slovenia is located in the Central Europe, with a population of only about two million. Therefore foreign language education is important. Foreign language learning (mostly English or German) starts formally at the age of nine (Year 4 of primary school) and continues for all students till the age of 15 (Year 9). In Year 7 (age 12) a compulsory second foreign language is introduced (German, Italian, Hungarian, Croatian, French and English). The criteria for the compulsory foreign languages set are based on priority treatment of the neighbouring languages, national minorities' languages and the working languages of the EU. However, foreign language education informally starts at preschool (at 3 to 6 years of age) and in the first cycle of primary school (6 to 8 years of age), mostly due to pressure from parents and society to start learning foreign languages earlier (Dagarin Fojkar, Skela, \& Kovač, 2013, p. 21), and funded by the local community or by fees (Brumen, 2011). To change the current situation the Ministry of Education is planning (in September 2014) to gradually introduce the first foreign language instruction as a compulsory subject in Year 2 (and as a non-compulsory subject in Year 1) of primary school. 
Learners should reach A2 at the end of Year 9 (age 15) in their first foreign language, in accordance with the Common European Framework (CEF) for Languages. The Slovenian curriculum for foreign languages is based on the communicative approach. It offers objectives, contents, standards of proficiency, and methodological recommendations for foreign language education in the second and third cycle of primary school (age 9 to 15). However, it does not involve any recommendations about how to work with students who have learning difficulties in learning foreign languages.

All teachers in schools are informed about individuals who have been officially diagnosed as pupils with learning difficulties, and they receive some general guidelines (Magajna et al., 2008a) about how to use different teaching strategies for working with them and how to find their own personal approaches for teaching and learning languages.

The purpose of this study was to determine the existing methodical and organisational elements of support in (Slovenian) foreign language teaching for students who have learning difficulties and to prepare some recommendations for foreign language teachers on dealing with these students in primary and lower-secondary schools.

\section{Theoretical Framework}

Various researches (Marcos, 1998; Ganschow, Sparks, \& Javorsky, 1998) have shown that students with learning difficulties can readily learn a foreign language (FL). Genesee (1976, in Marcos, 1998), in his research, found that when learning a foreign language, "students of average and below-average IQ performed as well as students of above-average IQ on oral production and interpersonal communication tasks". In the field of cross-disciplinary research (special education and foreign language learning), there have been studies that deal with learning difficulties in learning and teaching foreign languages. Various findings in professional publications dealing with this topic (e.g. Pompian \& Thum, 1988; Ganschow \& Sparks, 1987; Sparks, Ganschow, \& Pohlman, 1989; Ganschow, Sparks, \& Javorsky, 1998, p. 248) discuss why some students do well in some courses (e.g. mathematics, science, social studies) and do not perform well in or fail foreign language courses. Sparks and Ganschow (1991) proposed the Linguistic Coding Differences Hypothesis (LCDH) as a model for understanding foreign language learning difficulties. This hypothesis explains (Ganschow, Sparks, \& Javorsky, 1998, p. 248) that students' foreign language (FL) learning difficulties are related to similar problems in learning their native language (e.g. problems with reading, spelling, writing, oral language, vocabulary, pronunciation). However, Viskari $(2005$, p. 7) argues that FL difficulties are manifested in many forms and in many areas of language use in different combinations. We also want to emphasize that with learning difficulties, there may also occur other characteristics, such as attention deficits, problems in meta-cognition and memory, perceptual disorders, deficits in the area of social skills and in other areas (Lerner, 2003; Mercer \& Pullen, 2005).

Studies concerning FL learning have pointed out that the difficulties students have in foreign language learning may result from many different aspects of the learning situation as well as the student's personal characteristics. It has also been argued (Viskari, 2005, p. 108) that there is a gap between theory and practice in this field; the information of studies is scattered and needs to be made more available to the teachers who are faced with these problems and have the power to make changes in the classroom. Therefore there seemed to be a need for a study that would encourage reflective teaching and improve the situation in the (Slovenian) FL classroom.

Several studies have been carried out on upper-secondary school (Viskari, 2005) and college/university-level students (Ganschow, Sparks, \& Javorsky, 1998) who have learning difficulties in foreign language learning. However, foreign language learning and teaching with young learners who have learning difficulties at the primary and lower secondary level is, nevertheless, outside their scope. Various studies (Curtain \& Dahlberg, 2004; Edelenbos, Johnstone, \& Kubanek, 2006) suggest that children who learn languages before adolescence perform better academically, and cognitively. They also obtain personal and social benefits, a native-like pronunciation, and develop an innate ability to acquire the rules of any language. Therefore, the aim of this study is to present the current forms of teacher support for students with learning difficulties in a foreign language. Our study focused on English as a foreign language in an inclusive oriented elementary school (learners 9-15 years old). An extensive Slovenian study (Magajna et al., 2008b) on the situation of working with pupils with learning difficulties in primary schools has brought attention to the general need to overcome the many barriers that stand in the way of providing inclusive education for these students, which is the reason for our study.

The beginnings of organized support for pupils with learning difficulties in Slovenia started in the 1980s, when a mobile special educational service was designed for pupils with learning difficulties at the primary school level (Opara \& Trunkl, 1992). In recent years the need for mobilized special educators has been increasing together with the number of children with a variety of developmental disorders and learning difficulties in primary and 
lower-secondary schools. With the adoption of new education laws (Law on Primary School 1996, Law on directing Children with Special Needs, 2000, 2007) and with the introduction of inclusive education, schools had to adjust their methods and forms of work to ensure the implementation of supplementary classes and other forms of individual and group assistance for pupils with learning difficulties (mild and moderate). A group of experts at the Ministry of Education prepared a professional document "The concept of working with pupils with learning difficulties" (Magajna et al., 2008a) that dealt with increasing the responsibility for dealing with learning difficulties, providing early assistance to pupils and developing good teaching practice in schools. The document was intended for teachers and other education professionals. It presents guidelines for working with the above-mentioned group of pupils. Among the groups of children with special needs, the largest (50\%) are those with learning difficulties, which is also similar in other countries (Opara et al., 2010), such as the USA and Canada (Gargiulo, 2007). Therefore, comprehensive and systematic consideration must be given to children with learning difficulties that can lead to the development of appropriate strategies for teaching in this field. Primary and lower-secondary schools have to provide adaptations and additional professional support for pupils who have been officially diagnosed with more intensive learning difficulties. The children with learning difficulties are defined as a heterogeneous group of children who exhibit developmental delays in attention, memorisation, thinking, coordination, communication, social abilities and emotional maturation. Significant difficulties occur in the acquisition and use of reading, writing, orthographic/spelling and mathematical abilities (Official Gazette of Republic of Slovenia, 2003). There is an evident discrepancy between general intelligence capacities and actual academic achievements.

With the introduction of inclusive education and by analyzing foreign school practice, it can be seen that positive changes in school practice can be achieved with the development of cooperation and effective teamwork between teachers, special educators and other professionals; by effective learning and teaching strategies customized to pupils' needs; and by the involvement of parents, teacher training and the availability of sources for help (e.g., additional staff, peers, material, and financial resources) (McLeskey, Hoppey, Williamson, \& Rentz, 2004; Wagner, 2001; Villa et al., 1996; Kavale \& Forness, 2000). The role of the teacher in the development of inclusive education is of essential importance. Therefore professional teacher education and training is one of the priorities in all European countries (European Agency for Development in Special Needs Education, 2003). In addition to this, Slovenian teachers are expected to acquire additional education, be competent in this field, develop good teaching practices, be able to work in teams with colleagues and form partnerships with parents. Past experiences in working with pupils with learning difficulties confirm that the special educators are most often those professionals who help teachers in selecting teaching methods, adaptations, learning aids and planning and monitoring a pupil's learning progress in an inclusive classroom. They are also actively involved in helping to solve problems (Stopar, 1999; Schmidt, 2006). An important support to FL teachers can also provide parents of pupils who have learning difficulties, but only if the parents are motivated to cooperate with the FL teacher and actively participate in making decisions concerning their child's learning goals, formally and informally. Parental involvement enhances students' learning achievements and outcomes (Hill, 2001; Epstein \& Sanders, 2002; Grolnick, Ryan, \& Deci, 1991) and helps to avoid long-term negative consequences that can lead to negative results in school (Reynolds \& Clements, 2005).

In classes with pupils who have learning difficulties, other effective strategies that are vital for the development of inclusion can be implemented. These strategies (e.g., collaborative team teaching, reciprocal teaching, cooperative learning, peer tutoring, and structured peer support (Zionts, 1997; Fisher, Frey, \& Thousand, 2003) can also help FL teachers in their general workload.

Slovenian FL teachers are familiar with the above-mentioned general guidelines for working with pupils who have learning difficulties. However, there do not exist any specific recommendations, documents or approaches on how to work with this group of students in foreign language classes.

Taking this into account, the main research question in this study was to investigate which methodical and organisational aspects of support are offered to Slovenian foreign language teachers that help them to teach students who have learning difficulties in foreign language learning at the primary and lower-secondary level (between the ages of 9 and 15), according to the location of the school, being either urban or rural. These students are individuals with learning difficulties (individuals who have difficulties in FL courses) and individuals who have been officially diagnosed as pupils with learning difficulties and have extensive impairments in reading, writing, orthographic/spelling, attention and memorisation. They have this special status in order to help them improve their learning styles; it also gives their FL teachers the opportunity to adjust and change their teaching methods so that it will suit each individual.

The three research questions were as follows: (1) How do teachers of foreign languages implement collaborative 
team teaching in foreign language classes? (2) Do they organize regular consultation hours specifically for parents of children with learning difficulties? and (3) Do they keep a language portfolio for individual pupils with learning difficulties, according to the location of the school?

\section{Method}

Our research is based on the descriptive and causal-non-experimental methods of empirical pedagogical research. The data was collected on a non-random sample of 47 EFL teachers from 18 Slovenian primary and lower-secondary schools. Questionnaires were given to 200 EFL teachers. Unfortunately, only 47 EFL teachers responded (23.5\%), and these are included in the current study. The authors tried to get more feedback from the teachers (by e-mails and phone calls) in order to get more significant responses that would confirm the findings of our study, but their responses showed that they had an unwillingness to complete the questionnaire. We assume that this is due to work overload in their classes or lack of knowledge on this issue. Therefore, the results cannot be generalized according to a specific population, but represent a selected case study.

The sample of teachers we used included 51.1\% from urban schools and 48.9\% from rural schools.

Individual teachers in primary schools were given questionnaires in person or by e-mail. At our request, they forwarded the questionnaires to their colleagues in other school departments, and returned them to us completed.

As a measurement tool for the empirical research, we used a questionnaire consisting of closed-type questions. The questionnaire included specific elements of teacher-support for pupils with learning difficulties. The questionnaire provided us with the following characteristics: validity (conducted on the basis of scientific literature; Magajna et al., 2008a, 2008b; Kavkler, 2011), including a pilot study; reliability (exact instructions and clear, specific questions); and objectivity (closed-type questions).

The data was collected in 2012 .

The data was analyzed by use of descriptive and inferential statistics (f, $\mathrm{f} \%, \chi^{2}$-test of independence). The results we obtained are presented in tables. We mostly wanted to determine the differences according to school location, mainly because village schools are generally attended by fewer students. This lower pupil population, consequently, provides more time to develop dialogues between foreign language teachers, special educators, pupils with learning difficulties, their parents and their peers. This additional dialog helps to solve learning problems and poor school achievements. It also provides more opportunities to implement individual elements of support.

\section{Results}

The results are presented in three segments: 1. Implementing collaborative team teaching in foreign language classes, 2. Organizing regular consultation hours specifically for parents of children with learning difficulties and 3. Keeping a language portfolio for individual pupils with learning difficulties.

\subsection{Implementing Collaborative Team Teaching in Foreign Language Classes}

Collaborative team teaching is one of the most successful means of supporting pupils with learning difficulties (Lerner, 2003; Magajna et al., 2008b). A good model for collaborative team teaching can be described as follows: the cooperation between two teachers (the foreign language teacher and special educator), who share common responsibilities and tasks in achieving educational goals in an inclusive classroom (Friend \& Bursuck, 1999). It provides a situation where there is a respect for the differences between pupils, an encouragement of social contacts and an emphasis on the strengths and abilities of children who have learning difficulties (Zionts, 1997). When deciding for this form of teaching, it is important to define the role of both teachers, for example, who has the leading role and who has a supporting role (Friend \& Bursuck, 1999). Foreign language teachers can, for example, completely conduct the learning process and interpret the subject matter, and the special educator can directly support individuals with visual and nonverbal incentives, give additional explanations to smaller groups or read texts out loud that supplement the teaching of the first teacher (Zionts, 1997). Schools that practice quality inclusive teaching have shown the benefits of team-teaching with two teachers, both for the pupils with difficulties and those without difficulties (Frederickson, Dunsmuir, Lang, \& Monsen, 2004, Schmidt, 2006).

Ganschow, Sparks and Javorsky (1998, p. 254) also claim that conversations with a special educator can be useful in helping teachers decide on appropriate methods (e.g. offering un-timed tests, slowing the pace of verbal instruction, adding visual examples to verbal explanations in the FL) and give attention to students' specific needs.

The frequency that team teaching was performed in English lessons was measured with a rating scale from 1 (very often) to 5 (never). Collaborative team teaching in foreign language classes (Table 1) in urban schools was 
performed occasionally $(29.2 \%)$, rarely $(33 \%)$ or never $(37.5 \%)$. In village schools, collaborative team teaching was implemented occasionally $(17.4 \%)$, rarely $(26.1 \%)$, or never $(43.5 \%)$. The results show that collaborative team teaching in foreign language classes in both urban and rural schools is performed rarely $(29.8 \%)$ or is not implemented at all (40.4\%). The results (Table 1) between the two school locations show that there is no statistically significant difference $\left(\chi^{2}=0.799, \mathrm{P}=0.670\right)$ between urban and rural schools in the frequency of collaborative team teaching in foreign language lessons. In both school locations, collaborative team teaching in English lessons proved to be a poorly utilized source of support for pupils with special needs.

Table 1. Frequency of collaborative team teaching in foreign language classes according to school location*

\begin{tabular}{lllllll}
\hline & \multicolumn{2}{l}{ School location/Rural } & \multicolumn{2}{l}{ School location/Urban } & Total \\
\cline { 2 - 7 } & $\mathrm{f}$ & $\mathrm{f} \%$ & $\mathrm{f}$ & $\mathrm{f} \%$ & $\mathrm{f}$ & $\mathrm{f} \%$ \\
\hline Very often & 0 & 0.0 & 2 & 8.7 & 2 & 4.3 \\
Often & 0 & 0.0 & 1 & 4.3 & 1 & 2.1 \\
Occasionally & 7 & 29.2 & 4 & 17.4 & 11 & 23.4 \\
Rarely & 8 & 33.3 & 6 & 26.1 & 14 & 29.8 \\
Never & 9 & 37.5 & 10 & 43.5 & 19 & 40.4 \\
Total & 24 & 100.0 & 23 & 100.0 & 47 & 100.0 \\
\hline
\end{tabular}

Note*: Due to the low numbers, we excluded the categories "very often" and "often" from the table.

The results obtained are certainly not encouraging. We assume that for the implementation of such teaching, certain conditions have not been fulfilled. It is often difficult to coordinate schedules and find enough time for implementing team teaching. Special educators in schools deal with a large number of pupils with learning difficulties and are burdened with many other tasks (work with parents, additional professional support, and preparation of individualized programs). They are left with too little time for communication, cooperation and coordination (Friend \& Bursuck, 1999; Magajna et al., 2008b). A shortage of special education experts is also a problem. The reasons that collaborative team teaching is such an underutilized resource by foreign language teachers is due to various factors, such as limited teacher education and training (in a foreign language) in the field of working with pupils with learning difficulties; teamwork and cooperation in inclusion; and poor preparation skills when attempting such forms of cooperation.

FL teachers need to be aware that collaborative team work in additional, special courses for students with learning difficulties help these students in various ways (Viskari, 2005): improving the pupils moods, providing new ways of thinking, reducing pupil anxiety levels, allowing pupils the opportunity to experience success, allowing the pupils to concentrate better, and giving the pupils a more broad view of individual learning. Therefore, collaborative team teaching in foreign language classes helps FL teachers to focus on the learner's difficulty and needs in a foreign language and offers them more individual support.

\subsection{The Organization of Special Consultation Hours for Parents with Children Who Have Learning Difficulties}

The active involvement of parents in their children's schooling has a positive impact on the process of pupils' education, the process of socializing and the pupils' general sense of well-being (Kovacs-Cerović, Vizek-Vidovic, \& Powell, 2010; Powers, Hauser, \& Kilner, 1989). Consultation hours and individual parent-teacher conferences are the most common forms of formal cooperation between parents and teachers. During consultation hours, with an emphasis on informative discussion, the teacher informs the parents and talks with them about the educational accomplishment, characteristics and particularities of a pupil. However, in practice, it often happens that the consulting hours often turn into a review of a pupil's grades, which raises the pressure on the parents of children with learning difficulties. It can also bring up unfavourable feelings that are associated with any negative experiences related to school success or grades from previous years. Powers, Hauser, and Kilner (1989) point out that parents who are frustrated because of a child's poor learning success and progress in school can develop inappropriate and unrealistic expectations of their child's schooling and become excessively protective and lenient toward the children. Many parents of children with learning difficulties also develop a negative attitude and do not want to cooperate with the school. Therefore, it is very important that the consulting hours, intended for parents of children with learning difficulties, are organized in a way that do not emphasize the children's learning failures and inabilities, but try to introduce their strengths, 
abilities, and social interests. Parents of children with learning difficulties should be more motivated to cooperate with the school, to strengthen their important role in a child's learning at home, to monitor their child, to record their progress and development, and to encourage them to actively form friendships (Bender \& Wall, 1994, Magajna et al., 2008b).

Table 2 shows that special consulting hours for parents of children with learning difficulties are organized in $58.3 \%$ of the urban schools and in $47.8 \%$ of the rural schools. A more detailed analysis of the results $\left(\chi^{2}=0.521\right.$, $\mathrm{P}=0.471$ ) indicates that there is no statistically significant difference between urban and rural schools in the organization of special consulting hours for parents of children with learning difficulties. Although village schools are generally attended by fewer students they do not use this advantage by offering more consultation hours for these parents. Studies have shown parental involvement in their children's schooling enhances their learning (Hill, 2001; Hornby, 2000; Epstein \& Sanders, 2002) and increases their motivation to achieve better results (Grolnick, Ryan, \& Deci, 1991). When FL teachers help parents become involved in their child's learning, for example by explaining some FL learning styles and techniques, they can help these pupils to avoid long-term negative consequences, such as failing a FL course or not completing school (Reynolds \& Clements, 2005).

Table 2. Organization of special consultation hours for parents with children who have learning difficulties according to school location

\begin{tabular}{lllllll}
\hline & \multicolumn{2}{l}{ School location/Rural } & \multicolumn{2}{l}{ School location/Urban } & \multicolumn{2}{l}{ Total } \\
\cline { 2 - 7 } & $\mathrm{f}$ & $\mathrm{f} \%$ & $\mathrm{f}$ & $\mathrm{f} \%$ & $\mathrm{f}$ & $\mathrm{f} \%$ \\
\hline Yes & 11 & 47.8 & 14 & 58.3 & 25 & 53.2 \\
No & 12 & 52.2 & 10 & 41.7 & 22 & 46.8 \\
Total & 23 & 100.0 & 24 & 100.0 & 47 & 100.0 \\
\hline
\end{tabular}

Taking into account the results of the survey, we believe that it is advisable to continuously and systematically organize consulting hours for parents of children with learning difficulties at school. Devoting more time and attention to their children would allow them to present their views and observations of the child. Consequently, teachers and parents could then look for the most appropriate ways to support the pupil together. When teaching a foreign language in the classroom, teachers can usefully apply the information provided by the parents. Well organized and prepared consulting hours can help create a positive and cooperative partner relationship with parents. All this certainly has a positive reflection on the development and progress of pupils with learning difficulties (Mitchell, 2008; Schmidt, 2006).

\subsection{Keeping a Language Portfolio for Individual Pupils with Learning Difficulties}

A language portfolio is a selection of a pupil's work and achievements. It also includes documents created in specified periods and includes both the pupil's and teacher's reflections (Morrow, 2004). This portfolio accompanies the learning process of the individual, preserves their achievements and makes it easier to plan the pupil's future learning and work in a foreign language. In this way, the language portfolio directs language learning. It is never finished and is constantly developing together with the pupil. Language portfolios can contain the following items: selected examples of daily work in the classroom, pre-examinations and examinations, evaluation sheets for behaviour, stories, projects, art samples, teacher observation sheets, the results of group projects, etc. Pupils can organize themselves and be more responsible using a language portfolio. Language portfolios should be available for pupil-teacher discussions, teacher-parent meetings (Lerner, 2003) and team meetings. Given the fact that more individuals are involved in helping the pupil (e.g., parents, professional colleagues in various fields, external experts), it is recommended that a pupil's language portfolio always be stored in the same place, for easy access.

Foreign language teachers are not familiar with keeping language portfolios (Table 3) or a product folder for pupils who have difficulty in a foreign language. Only $16.7 \%$ of the urban schoolteachers keep language portfolios. In rural schools, the proportion of teachers who make use of language portfolios is even lower, only $4.3 \%$. An analysis of the differences between rural and urban schools shows that there is no statistically significant difference $\left(\chi^{2}=1.875, \mathrm{P}=0.171\right)$ between the two locations in keeping language portfolios for individual pupils with learning difficulties. In both school locations this is an uncommon practice. 
Table 3. Keeping language portfolios for individual pupils with learning difficulties according to school location

\begin{tabular}{lllllll}
\hline & \multicolumn{2}{l}{ School location/Rural } & \multicolumn{2}{l}{ School location/Urban } & Total \\
\cline { 2 - 7 } & $\mathrm{f}$ & $\mathrm{f} \%$ & $\mathrm{f}$ & $\mathrm{f} \%$ & $\mathrm{f}$ & $\mathrm{f} \%$ \\
\hline Yes & 1 & 4.3 & 4 & 16.7 & 5 & 10.6 \\
No & 22 & 95.7 & 20 & 83.3 & 42 & 89.4 \\
Total & 23 & 100.0 & 24 & 100.0 & 47 & 100.0 \\
\hline
\end{tabular}

It is surprising that such a high percentage of the teachers surveyed (89.4\%) do not keep language portfolios. This is unfortunate, since the use of such folders is very practical and recommended, especially for students with learning difficulties (Lerner, 2003) and could be considered as an alternative to traditional exams. The reason that foreign language teachers, involved in this study, do not make use of language portfolios is that such student-centred approaches require more adjustment and more interaction between the foreign language teacher and the pupil (with learning difficulties) and between the pupils themselves. The design and implementation of such lessons is more advanced than traditional - frontal teaching.

For a foreign language teacher, developing and keeping a language portfolio requires a major investment in the field of counselling and supervising. Adjusting the subject matter and organizing the various work methods is also required. In this respect, the teacher's role becomes less traditional, meaning less about supervision and more about mentoring and counselling. And, at the moment, foreign language teachers are definitely not adequately prepared or trained to do this.

\section{Discussion}

The article presents the results of recent research on the links between special education and foreign language learning. The aim of the research was to improve FL teaching styles and to help FL teachers find their own personal approaches to working with individual students with learning difficulties in FL learning. The study examined the existing methodical and organisational elements of support that Slovenian FL teachers offer to students who have learning difficulties at the primary and lower secondary level. The findings confirm that Slovenian FL teachers organize different elements of support for pupils with learning difficulties, however, they are relatively underutilized in both locations (urban or rural): collaborative team teaching in foreign language classes is rarely implemented or not implemented at all; consulting hours specifically for parents of children with learning difficulties are organized only by half of the schools included in the study; and keeping language portfolios for individual pupils with learning difficulties in both districts is a rare practice.

Slovenian foreign language teachers who work in primary and lower-secondary schools do not make adequate use of the various elements of support for working with pupils with learning difficulties in foreign languages, according to the location of their school, being either urban or rural. Surprisingly, village schools, which form a smaller and more cohesive community, do not utilize the benefits that come from cooperation between foreign language teachers, special educators, pupils with learning difficulties and their parents. Utilizing such benefits would have a positive impact on the organization and quality of support for these pupils. It would promote an academically and personally supportive FL classroom climate. As well, it would maximise positive interdependence and achievement among learners (Viskari, 2005, p. 36) who have learning difficulties.

The study also shows that the Slovenian curriculum for foreign languages does not offer support or any other resources to FL teachers that would act systematically to help students with learning difficulties in their FL classes. Some general guidelines (Magajna et al., 2008a) are taken into account in FL assessment so that students have the possibility to obtain special arrangements and demonstrations of their knowledge. Therefore, there is a need for additional resources that FL teachers could apply to their classes, and a need for specific training in the area of teaching pupils with more intensive learning impairments (e.g. dyslexia). We suggest utilizing the following elements of support for FL classes:

1) Establishing conditions for motivated learning (e.g., helping the pupils in recognising their own personal learning styles and suggesting alternative ways of learning to help them to become more aware of the ways in which they can enhance their own comprehension and production of the foreign language; creating friendly and stress free conditions for the students so that they feel comfortable in asking for advice; reviewing a pupils' past language learning history in order to inform current teachers about a pupil's possible learning difficulties that 
they had in the past; providing frequent and constructive feedback to achieve a pupil's best learning progress);

2) Developing foreign language communication competency (e.g., frequent repetition and slowing the pace of oral instruction in the foreign language, focusing on selected sounds, vocabulary, pronunciation of new words and intonation features; additional explanation to the FL contents; frequent checking of understanding of FL oral and written instructions; reading known FL texts aloud, underlining parts of the FL texts; using a multisensory structured language methodology (teaching grammar, vocabulary and making use of the sound-symbol system of the foreign language (Sparks \& Ganschow, 1991);

3) Resources and material added to verbal explanations (e.g., frequent use of visual support like illustrations, pictures, photos, mind mapping, graphs; using CDs, CD-ROMs or computer games by which students can practise their language skills (at home) interactively and independently; recording their own speech on a tape and then comparing it to a model);

4) Organisation of time (e.g. sitting arrangement—close proximity to the teacher, extended time for FL oral preparations and writing during oral and written assessments (up to 50\%), and individual assessment).

By using this kind of support, FL teachers can monitor their students and pay attention to their progress, study various teaching techniques and learn about pupil-difficulties. They can also observe the pupils more thoroughly and better decide on further procedures, such as finding the pupils a special education teacher, determining the amount of available support and contacting parents.

The reasons for the infrequent use of the elements of teacher-support for pupils who are learning a foreign language in primary school can be traced to inadequate initial and in-service teacher education for FL work with pupils with learning difficulties (in foreign languages). This consequently, leads to a poor level of readiness for collaborative team teaching in a foreign language. At Slovenian Faculties of Education, prospective foreign language teachers do gain some knowledge in the area of special needs and learning difficulties, or they can attend short additional teacher training for inclusive teaching. But, unfortunately, as shown in the survey, effective support for pupils with learning difficulties in a foreign language is poorly utilized in practice.

Implementing inclusive teaching would mean redefining the (Slovenian) school system and the system of education for foreign language teachers. Therefore, the following points are of key importance: a concern for one's ongoing professional development, the teacher's systematic and (self) critical exploration of their own practice and quality team-cooperation in the spirit of interactive professionalism (Fullan \& Hargreaves, 1996). Therefore, constructive and collaborative methods of solving concrete situations are some of the key factors for the professional development of foreign language teachers, special educators and the school community as a whole. Foreign language teachers and special educators have key roles in inclusive schools because they advise and direct the learning process and become pupils' partners in the pursuit of common learning goals (Ganschow, Sparks, \& Javorsky, 1998). In this way, they encourage an individual's positive self-image, social inclusion and potential. This is the fundamental element required for upgrading the current learning situation. In practice, it all too often happens that at each continuing stage of learning, pupils have to start all over again from the beginning.

It is also necessary to raise the awareness of foreign language teachers about the use of alternative teaching support, such as language portfolios, cross-age peer tutoring and the use of modern approaches and technologies. These help to create more space for the individual linguistic progress of each pupil that has learning difficulties. This will assist them in searching for their own, new, innovative and successful ways of reaching their foreign language goals.

In the future, it would be sensible to systematically follow (or analyze) the implementation of support strategies and approaches for teaching pupils with learning difficulties in a foreign language on a large sample, a sample that would include all (Slovenian) primary schools that are inclusion oriented. It will also be necessary to acquire a more detailed view of the preparation of guidelines for working with the above-mentioned group of children intended for foreign language teachers and other professionals. How these guidelines will be put into practice will need to be monitored. It would also be advisable to investigate if researchers in this field are using strategies not included in any of the above-mentioned items, such as incorporating open-ended questions in questionnaires or using different data-gathering tools (e.g. interviews). This could provide more relevant information on what the participating FL teachers report about what they are doing. It would also be advisable to receive as much feedback as possible on learning difficulties from students at the primary and lower secondary levels. Added to this, a comparative analysis of the use of support and strategies for working with pupils with learning difficulties in the international arena will also have to be researched.

\section{References}


Bender, W. N., \& Wall, M. E. (1994). Social emotional development of students with learning disabilities. Learning Disabilities Quarterly, 17, 323-341. http://dx.doi.org/10.2307/1511128

Booth, T., \& Ainscow, M. (Eds.). (1998). From Them to Us: An International Study of Inclusion in Education. London: Routledge.

Brumen, M. (2011). The perception of and motivation for foreign language learning in pre-school. Early child development and care, 181(6), 717-732. http://dx.doi.org/10.1080/03004430.2010.485313

Curtain, H., \& Dahlberg, C. A. (2004). Languages and Children: Making the Match: New Languages for Young Learners, Grades $K-8$ (3rd ed.). New York: Longman.

Fojkar, M. D., Skela, J., \& Kovač, P. (2013). A Study of the Use of Narratives in Teaching English as a Foreign Language to Young Learners. English Language Teaching, 6(6), 21-28. http://dx.doi.org/10.5539/elt.v6n6p21

Edelenbos, P., Johnstone, R., \& Kubanek, A. (2006). The Main Pedagogical Principles Underlying the Teaching of Languages to Very Young Learners. Brussels: European Commission. Education and Culture.

Epstein, J. L., \& Sanders, M. G. (2002). School, family, and community partnerships. In D. L. Levinson, P. W. Cookson, \& A. R. Sadovnik (Eds.), Education and sociology: An encyclopedia (pp. 525-532). New York: Routledge Falmer.

European Agency for Development in Special Needs Education. (2003). Special Needs Education in Europe. Thematic Publication. With the contribution of Eurydice. Retrieved from https://www.european-agency. org/publications/ereports/special-needs-education-in-europe/sne_europe_en.pdf

Frederickson, N., Dunsmuir, J., Lang, J., \& Monsen, J. J. (2004). Mainstream-Special school partnerships: Pupil, parent and teacher perspectives. International Journal of Inclusive Education, 8(1), 37-57. http://dx.doi.org/10.1080/1360311032000159456

Fisher, D., Frey, N., \& Thousand, J. S. (2003). What do special educators need to know and be prepared to do for inclusive schooling to work? Teacher Education and Special Education, 26(1), 42-50. http://dx.doi.org/10.1177/088840640302600105

Friend, M., \& Bursuck, W. D. (1999). Including Students with Special Needs: A Practical Guide for Classroom Teachers. Boston, MA: Allyn \& Bacon.

Fullan, M., \& Hargreaves, A. (1996). What's Worth Fighting for in Your School? New York: Teachers College Press.

Ganschow, L., Sparks, R. L., \& Javorsky, J. (1998). Foreign language learning difficulties: A historical $\begin{array}{lllll}\text { perspective. Journal of Learning } & \text { 248-258. }\end{array}$ http://dx.doi.org/10.1177/002221949803100304

Ganschow, L., \& Sparks, R. (1987). The foreign language requirement. Learning Disabilities Focus, 2, 116-123.

Gargiulo, R. M. (2007). Special Education in Contemporary Society: An Introduction to Exceptionality. Belmont, CA: Thomson Wadsworth.

Genesee, F. (1976). The Role of Intelligence in Second Language Learning. Language Learning, 26(2), 267-280. http://dx.doi.org/10.1111/j.1467-1770.1976.tb00277.x

Grolnick, W. S., Ryan, R. M., \& Deci, E. L. (1991). The inner resources for school achievement: Motivational mediators of children's perceptions of their parents. Journal of Educational Psychology, 83, 508-517. http://dx.doi.org/10.1037//0022-0663.83.4.508

Hill, N. E. (2001). Parenting and academic socialization as they relate to school readiness: The roles of ethnicity and family income. Journal of Educational Psychology, 93, 686-697. http://dx.doi.org/10.1037//0022-0663.93.4.686

Hornby, G. (2000). Improving parental Involvement. London and New York: Cassell.

Kavale, K. A., \& Forness, S. R. (2000). History, Rhetoric, and Reality Analysis of the Inclusion Debate. Remedial and Special Education, 21(5), 279-296. http://dx.doi.org/10.1177/074193250002100505

Kavkler, M. (2011). Konceptualne osnove obravnave učencev z učnimi težavami (Conceptual Treatment of Pupils with Learning Difficulties). In M. Košak-Babuder, \& M. Velikonja (Eds.), Učenci z učnimi težavami-Pomoč in podpora (Pupils with Learning Difficulties-Help and Support) (pp. 8-42). Ljubljana: Pedagoška fakulteta Univerze v Ljubljani. 
Kovacs-Cerović, T., Vizek-Vidović, V., \& Powell, S. (2010). School Governance and Social inclusion: Involvement of Parents. Ljubljana: University of Ljubljana, Faculty of Education, Center for Educational Policy Studies.

Lerner, J. W. (2003). Learning Disabilities (9th ed.). Boston: Houghton Mifflin Company.

Stopar, M. L. (1999). Vloga defektologa pri timskem delu z učenci s posebnimi potrebami v osnovni šoli (The Role of Special Educator in Teamwork with Pupils with Special Needs in Primary and Lower-Secondary School). In J. Hytönen, C. R. Pučko, \& G. Smyth (Eds.), Izobraževanje učiteljev za prenovljeno šolo (Teacher Education for Renewed School) (pp. 65-72). Ljubljana: Pedagoška fakulteta.

Magajna, L., Kavkler, M., Vogrinčič, G. C., Pečjak, S., \& Golobič, K. B. (2008a). Učne težave v osnovni šoli: koncept dela. Program osnovnošolskega izobraževanja (Learning Difficulties in Primary and Lower-Secondary School: The Concept of Work. The Primary and Lower-Secondary School Programme). Ljubljana: Zavod RS za šolstvo.

Magajna, L., Pečjak, S., Peklaj, C., Vogrinčič, G. C., Golobič, K. B., Kavkler, M., \& Tancig, S. (2008b). Učne težave $v$ osnovni šoli-problemi, perspektive, priporočila (Learning Difficulties in Primary and Lower-Secondary School-Problems, Perspectives and Recommendations). Ljubljana: Zavod RS za šolstvo.

Marcos, K. M. (1998). Second language learning: Everyone can benefit. The ERIC Review, 6(1), 2-5, Retrieved from http://www.cal.org/earlylang/benefits/marcos.html

McLeskey, J., Hoppey, D., Williamson, P., \& Rentz, T. (2004). Is inclusion an illusion? An Examination of National and State Trends Towards the Education of Students with Learning Disabilities in General Education Classroom. Learning Disabilities: Research \& Practice, 19(2), 109-115. http://dx.doi.org/10.1111/j.1540-5826.2004.00094.x

Mercer, C., \& Pullen, C. (2005). Students with Learning Disabilities (6th ed.). Upper Saddle River, NJ: Pearson education.

Mitchell, D. (2008). What really Works in Special and Inclusive Education. London-New York: Routledge.

Morrow, K. (Ed.). (2004). Insights from the Common European Framework. Oxford: OUP.

Official Gazette of Republic of Slovenia, No. 12. (1996). Law on Primary School. Ljubljana: Ministry of Education and Sports.

Official Gazette of Republic of Slovenia, No. 54. (2000). Law on Directing Children with Special Needs. Ljubljana: Ministry of Education and Sports.

Official Gazette of Republic of Slovenia, No. 3. (2007). Law on Directing Children with Special Needs. Ljubljana: Ministry of Education and Sports.

Official Gazette of the Republic of Slovenia, No. 54. (2003). Rules of the Organisation and Methods of Work for Commissions in the Directing of Children with Special Needs and on Criteria for Identifying the Type and Degree of Disadvantages, Impairments and Disabilities of Children with Special Needs. Ljubljana: Ministry of Education and Sports.

Opara, B., \& Trunkl, R. (1992). Obravnavanje šoloobveznih otrok s težavami v razvoju in učenju (Dealing with School-age Children with Developmental and Learning Disabilities). Ljubljana: Zavod Republike Slovenije za šolstvo in šport.

Opara, B., Lakota, A. B., Globačnik, B., Grum, D. K., Košir, S., Lukšič, M. M., ... Klavžar, K. (2010). Analiza vzgoje in izobraževanja otrok s posebnimi potrebami v Sloveniji (Analysis of the Education of Children with Special Needs in Slovenia). Ljubljana: Pedagoški inštitut.

Pompian, N., \& Thum, C. (1988). Dyslexic/learning Disabled Students at Dartmouth College. Annals of Dyslexia, 38(1), 276-284. http://dx.doi.org/10.1007/BF02648261

Powers, S. I., Hauser, S. T., \& Kilner, L. A. (1989). Adolescent mental health. American Psychologist, 44(2), 220-228. http://dx.doi.org/10.1037//0003-066X.44.2.200

Reynolds, A. J., \& Clements, M. (2005). Parental involvement and children's school success. In E. N. Patrikakou, R. P. Weisberg, S. Redding, \& H. J. Walberg (Eds.), School-family partnerships for children's success. New York: Teachers College Press.

Schmidt, M. (2006). Zaznavanje integracije/inkluzije v osnovni šoli (Detection of Integration/Inclusion in 
Primary and Lower-Secondary School). Sodobna pedagogika, 57(123), 320-337.

Sleeter, C., \& Grant, C. (2003). Making Choices for Multicultural Education (4th ed.). New York: Wiley.

Sparks, R., Ganschow, L., \& Pohlman, J. (1989). Linguistic coding deficits in foreign language learners. Annals of Dyslexia, 39, 179-195. http://dx.doi.org/10.1007/BF02656908

Sparks, R. L., \& Ganschow, L. (1991). Foreign Language learning differences: Affective or native language aptitude differences? Modern Language Journal, 75(1), 3-16. http://dx.doi.org/10.1111/j.1540-4781.1991.tb01076.x

Villa, R., Thousand, J., Meyers, H., \& Nevin, A. (1996). Teacher and administrator perceptions of heterogeneous education. Exceptional Children, 63, 29-45.

Viskari, K. (2005). Foreign Language Learning Disabilities: Theoretical and Practical Tools for English Teachers in Finnish Upper Secondary Schools (A Pro Gradu thesis, University of Jyväskylä, Jyväskylä).

Wagner, T. (2001). Leadership for learning: An action theory of school change. Phi Delta Kappan, 82(5), 378-383.

Zionts, P. (1997). Inclusion Strategies for Students with Learning and Behavior Problems. Austin, TX: Pro-ed.

\section{Copyrights}

Copyright for this article is retained by the author(s), with first publication rights granted to the journal.

This is an open-access article distributed under the terms and conditions of the Creative Commons Attribution license (http://creativecommons.org/licenses/by/3.0/). 